\title{
PROBENECID, NEPHROTIC SYNDROME, AND RENAL FAILURE
}

\author{
BY \\ J. T. SCOTT* AND P. K. O'BRIEN $\dagger$ \\ From the Department of Medicine, Royal Postgraduate Medical School, \\ and the Department of Pathology, Paddington General Hospital, London
}

This report describes two patients in whom oedema and proteinuria occurred during treatment with the uricosuric agent probenecid. In one of them these features were accompanied by hypoalbuminaemia and hypercholesterolaemia, recovery following withdrawal of the drug. In the other there was renal failure from which the patient died.

Case 1, an electrical engineer, had had recurrent gouty arthritis since the age of 14 years. A paternal uncle had also suffered with gout. From the age of 50 onwards numerous tophi appeared on the hands, feet, elbows, and ears. At one time or another he had been given various drugs, including corticosteroid hormones, phenylbutazone, salicylates, and probenecid. These drugs had produced no harmful effects, but he had not taken any of them for more than a few days or weeks. There was no history of exposure to any other chemicals.

He was first admitted to Hammersmith Hospital in November, 1962, when he was 60 years of age.

Examination.-He was rather obese, weighing $94 \mathrm{~kg}$. There were changes of chronic gouty arthritis with multiple tophi, some of them discharging. The heart was slightly enlarged but examination showed no other abnormalities. There was no oedema.

The blood pressure was 130/80. The serum uric acid lay between 9.2 and $12.5 \mathrm{mg} . / 100 \mathrm{ml}$. and impairment of renal function was indicated by a blood urea of between 82 and $116 \mathrm{mg} . / 100 \mathrm{ml}$., phenosulphthalein excretion of 24 per cent. in one hour (normal 40-60 per cent.), and maximum urine concentration of 1016. The urine contained no protein, or a trace only, there were no abnormal deposits, and culture was sterile. Erythrocyte sedimentation rate $7 \mathrm{~mm}$./hr., Hb $16.6 \mathrm{~g}$. per cent.; white cells 7,000; serum albumin 3.9 g. $/ 100 \mathrm{ml}$.

Chest $x$ ray showed a slightly enlarged left ventricle. Intravenous pyelogram was normal.

Treatment.-He was given probenecid 1.0 g., colchicine $1.0 \mathrm{mg}$., and sodium bicarbonate $6.0 \mathrm{~g}$. daily.
Progress.-In April, 1963, he was feeling well but the serum uric acid remained elevated at $10.0 \mathrm{mg} . / 100 \mathrm{ml}$. The blood urea was $96 \mathrm{mg} . / 100 \mathrm{ml}$. The urine contained a trace of protein. The same treatment was continued.

In July, 1963, there was the onset of swelling of both legs which persisted over the following month. In October there was an episode of pain and tenderness in the right calf. The patient was re-admitted to Hammersmith Hospital in December, 1963, with gross oedema of the legs. Jugular venous pressure was slightly raised at $1 \mathrm{~cm}$. and the heart was slightly enlarged as before, but physical examination was otherwise negative.

The blood-pressure was 120/70. Serum uric acid $9 \mathrm{mg} . / 100 \mathrm{ml}$., blood urea $76 \mathrm{mg} . / 100 \mathrm{ml}$. There was now heavy albuminuria ( $23 \mathrm{~g} . / 24 \mathrm{hrs}$ ) but no other abnormality in the urine. The serum albumin had fallen to $1.6 \mathrm{~g}$. per cent.; serum cholesterol $490 \mathrm{mg}$./ $100 \mathrm{ml}$. Erythrocyte sedimentation rate $100 \mathrm{~mm} . / \mathrm{hr}$; $\mathrm{Hb} 12 \cdot 6 \mathrm{~g}$. per cent; white cells 4,000 .

The chest $x$ ray was unchanged; an electrocardiogram showed changes consistent with mild ischaemia.

Renal biopsy (Dr. E. K. M. Smith) showed a few foci of tubular atrophy and fibrosis (Fig. 1, overleaf). Crystal spaces were not seen. Examination for amyloid using Congo red staining and crossed polaroids was negative.

On January 3, 1964, probenecid was discontinued. The serum uric acid rose to $12 \mathrm{mg} . / 100 \mathrm{ml}$. and a few days later the patient had an acute attack of gout in the right knee. During the next 3 weeks, however, the oedema subsided, his weight fell from 102 to $88 \mathrm{~kg}$., albuminuria decreased to $1.5 \mathrm{~g} . / 24 \mathrm{hrs}$, the serum albumin rose to $3 \cdot 3 \mathrm{~g} . / 100 \mathrm{ml}$., and the serum cholesterol fell to $250 \mathrm{mg} . / 100 \mathrm{ml}$.

On January 27 treatment was commenced with allopurinol and colchicine.* Since then he has done well; he has been free of acute gout and chronic joint pain, the tophi are receding, serum uric acid $4.1 \mathrm{mg}$./ $100 \mathrm{ml}$., blood urea $87 \mathrm{mg} . / 100 \mathrm{ml}$. (January, 1967). There has been no recurrence of oedema, and no more than a trace of proteinuria.

*This aspect of the case has already been reported in detail (Hall, Holloway, and Scott, 1964; Case 1).
*Present address: Charing Cross Hospital, London, W.C.2 †Present addrees: The London Hospital, London E.1. 


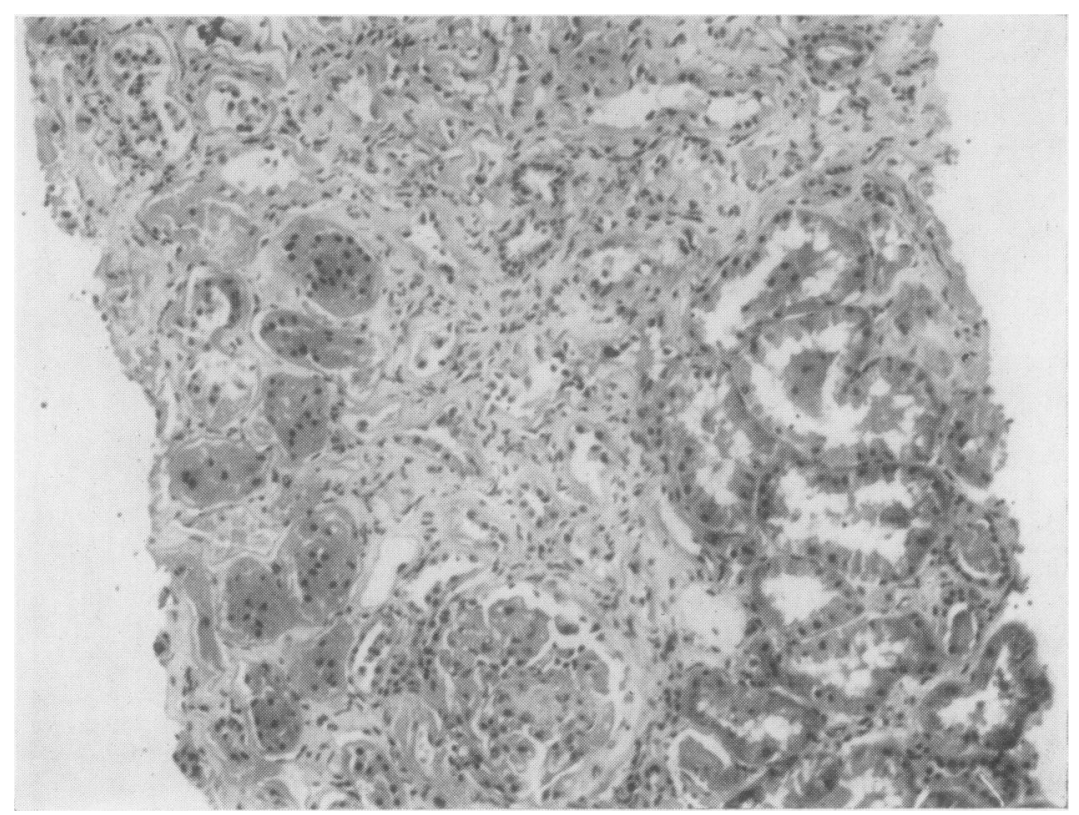

Fig. 1. - Renal biopsy from Case 1, showing foci of tubular atrophy and fibrosis. Haematoxylin and eosin. $\times 40$.

Case 2, a bank messenger, had previously had several other occupations but none involving exposure to industrial chemicals. His father had had gout and the patient first had an acutely painful toe in 1958 at the age of 67 years. The serum uric acid level was then $7 \mathrm{mg}$. $/ 100 \mathrm{ml}$. and a diagnosis of gouty arthritis was made, but no treatment was given.

Examination.-He attended Hammersmith Hospital in 1961 when physical examination was normal apart from minimal ankle oedema. The blood pressure was 180/110. The urine was normal, with no proteinuria or abnormal deposit, and was sterile on culture. Serum uric acid was $8.8 \mathrm{mg}$./100 ml.; blood urea $32 \mathrm{mg}$. $/ 100 \mathrm{ml}$.; Hb $16.6 \mathrm{~g}$. per cent.

In October, 1963, he had his second attack of acute gout, the serum uric acid being $8 \cdot 8 \mathrm{mg} . / 100 \mathrm{ml}$.

Treatment.-He was given maintenance colchicine 1.0 mg. daily.

In April, 1964, the serum uric acid was $9.8 \mathrm{mg} . / 100 \mathrm{ml}$. and treatment was commenced with probenecid $1.0 \mathrm{~g}$. daily: blood urea was then $38 \mathrm{mg} . / 100 \mathrm{ml}$. and the urine remained free of protein.

He was last seen at Hammersmith in June, 1965; he had continued to take probenecid and colchicine and had remained well with no further gout. Blood pressure 160/80; serum uric acid $4.2 \mathrm{~g}$. $/ 100 \mathrm{ml}$.; blood urea 47 $\mathrm{mg} . / 100 \mathrm{ml}$.
Termination.-On August 12 he was admitted tôّ Paddington General Hospital (Dr. A. I. Suchett-Kaye? with a 3-week history of anorexia, drowsiness, and $\overrightarrow{5}$ swelling of the limbs. Examination now showed exten 3 sive oedema of the hands, legs, and trunk.

The jugular venous pressure was not raised; blood pressure 180/110. The serum uric acid was now 8. mg. rising to $15.3 \mathrm{mg}$. $/ 100 \mathrm{ml}$.; blood urea $204 \mathrm{mg}$. f $100 \mathrm{ml}$; ; plasma bicarbonate $19 \mathrm{mEq} / 1$.; $\mathrm{Hb} 10.0 \mathrm{~g}$. pes cent.; white cells 6,900; erythrocyte sedimentation rate $34 \mathrm{~mm}$./hr; L.E.-cells negative. There was heavo proteinuria $(11.0 \mathrm{~g} . / 24 \mathrm{hrs})$ and the urine contained granular casts and coliform organisms. The serumb albumin was $4 \cdot 2 \mathrm{~g} . / 100 \mathrm{ml}$.

Treatment with probenecid was continued, together. with a number of diuretics and antibiotics. The course was one of progressive oedema, ascites, uraemia, and acidosis, and the patient died on September 18, 1965.

Post mortem Examination.-There was marked oedemß of the trunk and extremities. The heart was enlarged (445 g.) because of concentric hypertrophy of the lef ventrical. Both kidneys were large and pale, the lefe weighing $235 \mathrm{~g}$., and the right $225 \mathrm{~g}$. On slicing there was seen to be good corticomedullary demarcation. The renal veins and inferior vena cava were normal. Histo logical examination of both kidneys showed widespreas dilatation of cortical tubules with flattening of the lining epithelium (Fig. 2). Many collecting tubules containe proteinaceous casts. Crystals were visible in severa distal convoluted and collecting tubules and were presenf 


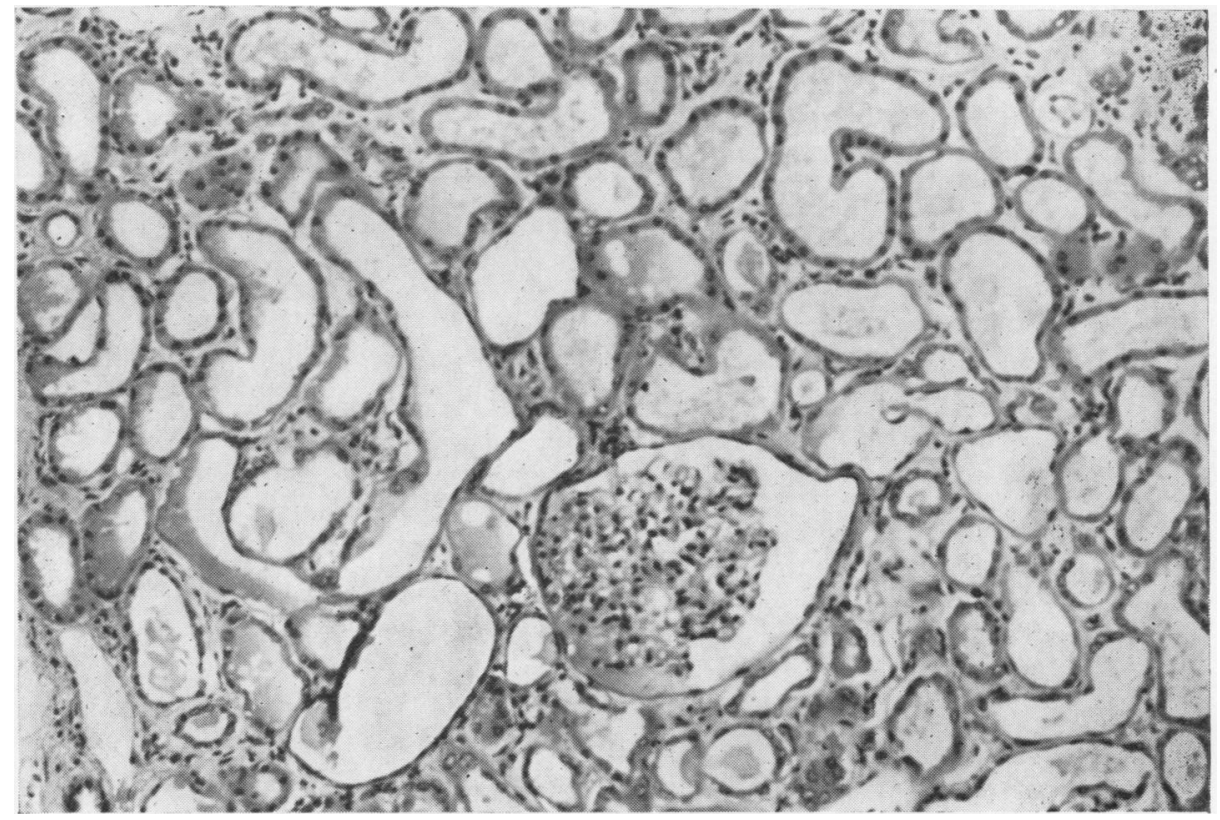

Fig. 2.-Section of kidney from Case 2, showing dilatation of cortical tubules with flattening of lining epithelium. Haematoxylin and eosin. $\times 40$.

also in the interstitial tissues of the medulla. In addition there was marked oedema of the interstitial tissue of both cortex and medulla on both sides, which accounted for the increased weight of the kidneys. The glomeruli showed no abnormality on light microscopy. Examination for amyloid was negative.

\section{Discussion}

There have been two previous reports of nephrotic syndrome apparently caused by probenecid. Ferris, Morgan, and Levitin (1961) described the case of a man with gout who within 4 months of starting treatment with probenecid developed oedema, which disappeared when the drug was stopped. Probenecid was recommenced on two subsequent occasions, and on each he again became oedematous, with proteinuria and hypoalbuminaemia, recovery following withdrawal of the drug. Sokol, Bashner, and Okun (1967) described a similar patient who developed the nephrotic syndrome 3 months after starting probenecid. Recovery followed withdrawal, and the same sequence was repeated when a further attempt was made to administer the drug. Renal biopsy carried out during the first recovery phase showed no abnormality apart from precipitated protein in Bowman's spaces and in the convoluted tubules.

It is conceded that the evidence associating the development of oedema and proteinuria with the use of probenecid in our two patients is by no means conclusive. Case 1 was known to have pre-existing chronic impairment of kidney function although there was no history of any disease other than gout. The transient episode of calf tenderness which occurred 3 months after the onset of oedema was diagnosed as leg vein thrombosis and raised the possibility that the nephrotic syndrome was due to venous thrombosis involving the inferior vena cava and renal veins. The improvement which followed withdrawal of probenecid, however, was striking and sustained. The clinical picture in Case 2 differed from that in Case 1 in that, although there was severe oedema and heavy proteinuria, the serum albumin was not lowered (cholesterol was not estimated) and renal failure led to death. The urine was infected during the terminal illness but there was no previous evidence of urinary infection or of kidney disease. The intervals between starting probenecid therapy and the onset of oedema were 8 and 15 months in the two patients, which is considerably longer than those in the other two reports. Both patients were also taking maintenance colchicine therapy, but this drug has never been noted to cause renal damage and Case 1 subsequently took colchicine (with allopurinol) over a prolonged period with no recurrence of oedema or proteinuria. Finally, the appearance of the renal histology was dissimilar in the two patients, the extensive bilateral D 
tubular changes seen in the second case having no counterpart in the first. Brown and Mallory (1950) record tubular atrophy and dilatation, both focal and generalized, as a finding in the gouty kidney, though none of their cases had generalized oedema or large pale kidneys, and all showed other renal complications such as nephrosclerosis or pyelonephritis.

Proteinuria and renal failure are seen to develop in a number of patients with gout (Talbott and Terplan, 1960) and the various associations between renal disease and hyperuricaemia are not fully understood. The mild chronic renal insufficiency in Case 1 may well be an example of this. However, neither a reversible nephrotic syndrome, as in Case 1, nor rapidly developing oedema, proteinuria, renal failure, and death occurring after only two attacks of podagra, as in Case 2 , have been described as,
complications of gout.

These two cases, therefore, considered in associa $\overrightarrow{\vec{s}}$ tion with the previous reports, raise the definite possibility that probenecid can cause such syndromes The drug has, however, been in widespread use fo over 15 years and renal complications of this type must be very rare.

\section{Summary}

Two patients with gout developed oedema and proteinuria 8 and 15 months after starting treatment with probenecid. In one patient rapid recoveryis from a full nephrotic syndrome followed withdrawa of probenecid, but the other continued to take the drug and died in renal failure. The possibility of causal association is discussed.

\section{REFERENCES}

Brown, J., and Mallory, G. K. (1950). New Engl. J. Med., 243, 325 (Renal changes in gout).

Ferris, T. F., Morgan, W. S., and Levitin, H. (1961). Ibid., 265, 381 (Nephrotic syndrome caused by probenecid).

Hall, A. P., Holloway, V. H., and Scott, J. T. (1964). Ann. rheum. Dis., 23, 439 (4-hydroxypyrazolo 3,4-d) pyrimidine (HPP) in the treatment of gout: preliminary observations).

Sokol, A., Bashner, M. H., and Okun, R. (1967). J. Amer. med. Ass., 199, 43 (Nephrotic syndrome caused by probenecid).

Talbott, J. H., and Terplan, K. L. (1960). Medicine (Baltimore), 39, 405 (The kidney in gout).

Probénécid, syndrome néphrotique et insuffisance rénale

\section{RÉSUMÉ}

Deux malades atteints de goutte présentèrent un oedème et une protéinurie 8 et 15 mois après le début d'un traitement par le probénécid. Un malade guérit rapidement d'un syndrome néphrotique majeur à l'arrêt du traitement mais l'autre, qui continuait à recevoir le même traitement, mourut dans un tableau d'insuffisance rénale. On discute la possibilité de l'existence d'une relation de cause à effet.
Probenecid, síndrome nefrótico e insuficiencia renal

\section{SUMARIO}

Dos enfermos con gota presentaron un edema y ung proteinuria 8 y 15 meses después de empezar tratamiento con probenecid. Uno de ellos recobró rapidamente de. un síndrome nefrótico clásico después de parar tratamiento, pero el otro, que seguía tomando el prob3 enecid, murió de insificiencia renal. Se discute la posibilidad de una asociación causal. 